Афанасьєв С.М., Майкова Т.В.

\title{
Особливості функціонального стану вегетативної нервової системи та адаптаційні можливості серцево-судинної системи дітей молодшего шкільного віку 3 порушеннями постави
}

\author{
Придніпровська державна академія фізичної культури і спорту, м. Дніпро, Україна
}

\begin{abstract}
3 метою оптимізації розробки програми фізичної терапї для учнів молодщего шкільного віку з порушеннями постави вивчений функиіональний стан вегетативної нервної системи та визначено адаптаційний потенціал серцево-судинної системи. В результаті дослідження вивявлені гендерні особливості вегетативної реактивності дітей молодмого шкільного віку з порушеннями постави.

Встановлено, щзо в стані спокою у 73,3\% хлопчиків $і$ 52,2\% дівчаток переважав вегетативний дисбаланс 3 домінуванням симпатикотонії як у хлопчиків, при вегетативному індексі Кердо $(30, \pm 1,46)$ ум.од., так $і$ у дівчаток $(33,2 \pm 2,2)$ ум.од.

При визначенні реакиії на кліноортопробу встановлено, щуо 54,9\% учнів мали відхилення від нормальних показників вегетативної реактивності, з формуванням патологічних варіантів: гіперсимпатикотонічного та асимпатокотнічного. При дослідженні вегетативної реативності в залежності від вихідного вегетативного тонусу виявилося, щзо нормальна реакиія була більш характерною для дітей з ейтонією, при симпатокотонії ейтонічний тип реагування на ортопробу спостерігався в 6,4 рази рідше. Для дітей з симпатикотонічним вихідним вегетативним тонусом, напроти більш характерним був гіперсимпатокотонічний тип ВР, який спостерігався в 3,7 рази частіше, ніж при вихідній ейтонії. Кореляційний зв'язок патологічних типів реагування ВНС з адаптаційним потенціалом сериево-судинної системи свідчить про напругу адаптивних механізмів при зниженні резервних можливостей вегетативної регуляиї, щчо необхідно враховувати під час розробки програм фізичної терапії для дітей молодшого шкільного віку з порушеннями постави.
\end{abstract}

Ключові слова: школярі молодшого шкільного віку, порушення постави, вегетативна реактивність, адаптаційний потенціал.

Вступ

$\mathrm{C}$ еред актуальних проблем суспільства особливе місце займає питання збереження і зміцнення здоров'я дітей. Відомо, що одним з критичних періодів розвитку дітей є молодший шкільний вік. Нові для дитини умови пристосування до навчальної діяльності та шкільного середовища загрожують значним напруженням і перенапруженням регуляторних систем $[1,2]$. В першу чергу це стосується вегетативної нервової системи (ВНС) [3].

Статистика захворювань школярів свідчить про те, серед дитячої популяції найбільш частими функціональними розладами кістковом'язової системи $є$ різні форми порушення постави, що за даними різних авторів складають від $33,4 \%$ до $72 \%$ дитячої популяції $[1,3,4]$.

В той же час у школярів поширеність зростає у дітей 31 класу до переходу до предметного навчання у 56 разів [5].

Деформація хребта $\epsilon$ вогнищем патологічної пропріоцептивної імпульсації, негативно позначається на всьому організмі дітей і не тільки на моторних функціях, a й регуляторних, зокрема, супроводжується вегетативними дисфункціями $[1,6]$.
Для розробки програм фізичної реабілітації дітей 3 порушеннями постави необхідна оцінка функціонального стану систем організму, відповідальних за формування постави, і фізичних якостей, що ііі визначають.

Причини і патогенетичні механізми формування порушень постави, за аналізом літератури, вивчені між тим, стан ВНС, особливо ï адаптивні можливості у дітей молодшого шкільного віку 3 порушеннями постави висвітлені недостатньо.

Особливістю дитячого віку є нестійкий гомеостаз внаслідок морфофункціональної перебудови організму дитини, пов'язаної з іiі розвитком, оцінка адаптивного реагування $є$ надзвичайно важливою [7].

Мета дослідження - дослідити функціональний стан вегетативної нервної системи та визначити адаптаційний потенціал дітей молодшего шкільного віку 3 порушеннями постави, як передумову розробки програми фізичної терапї.

Під спостереженням знаходилися 91 школяр 3 порушеннями постави у віці від 7 до 10 років, в тому числі 45 хлопчиків та 46 дівчаток у період з 2016 р. по 2019 р.

Адаптаційні можливості вегетативної нервової системи оцінювали за вегетативною реактивністю (ВР), яку визначали за ортостатичною пробою [9].

Фізіологічні механізми вегетативної регуляції використовували комплекс параметрів статистичного 
методу аналізу варіаційної пульсометрії (ВП), яку проводили при використанні автоматичного діагностичного комплексу "Кардіо-плюс" (НПП "Метекол", Україна), згідно загальновизнаним міжнародним стандартам AAMI (Association for the Advancement of Medical Instrumentation).

Вегетативний тонус визначали за інтегративним показником - вегетативним індексом Кердо (ВIК) [8].

Вегетативну реактивність оцінювали за ставленням індексу напруги в ортоположенні (IH-2) до індексу напруги в кліноположенні (IH-1). Обстеження проводили в першій половині дня через 1 годину після прийому їжі та 10-15-хвилинного відпочинку в комфортних для дитини умовах.

Для визначення IH аналізували основні показники ВП у спокої дитини та після ортопроби за методикою Р. М. Баєвського [9].

Вегетативну реактивність інтерпретували як нормотонічну, асимпатикотонічну [7].

Для визначення впливу ВР на адаптаційні можливості обстежених дітей, визначався рівень адаптаційного потенціалу (АП) серцево-судинної системи за формулою:

$$
\begin{gathered}
\mathrm{A \Pi}=0,011(\mathrm{ЧCC})+0,014(\mathrm{ATc})+0,008(\mathrm{AТд})+ \\
0,014(\mathrm{~B})+0,009(\mathrm{MT})-0,009(Д Т)-0,27,
\end{gathered}
$$

де АП - адаптаційний потенціал (бали), ЧСС частота серцевих скорочень (уд/хв.), АТс - артеріальний тиск систолічний (мм рт.ст.), АТд - артеріальний тиск діастолічний (мм рт.ст.), МТ - маса тіла, ДТ - довжина тіла (см), В - вік (роки) [5]
Статистична обробка результатів досліджень здійснювалася методами варіаційної статистики 3 використанням стандартного пакету прикладних програм SPSS 13.0 for Windows. Для статистичного аналізу даних використовували дескриптивну статистику. Кореляційний аналіз виконували за Пірсоном і Спірменом.

Дослідження проведені протягом 2016-2019 рр.

Етичні та правові проблеми дослідження вирішено у межах існуючих Міжнародних конвенцій та законодавства України, принципів біоетики в медичних дослідженнях. Робота виконана відповідно до вимог типового Положення 3 питань етики МО3 України (наказ MO3 України № 616 від 03.08.2012р.). Засоби вимірювань, що використані в роботі, пройшли держповірку у визначеному порядку. Спостереження та обстеження дітей здійснювалося за інформованою згодою з батьками.

\section{Результати дослідження та їх обговорення}

Порушення постави супроводжувалися синдромом вегетативної дисфункції, який проявлявся головним болем, запамороченням, підвищеною стомлюваністю, дратівливістю, порушенням сну, погіршенням пам'яті.

Аналіз результатів досліджень сідчить про переважання вегетативного дисбалансу в стані спокою у 73,3\% хлопчиків і 52,2\% дівчаток. В структурі виявлених змін домінувала симпатикотонія як у хлопчиків, при ВІК $(30, \pm 1,46)$ ум.од., так і у дівчаток $(33,2 \pm 2,2)$ ум.од.

При визначенні реакції на кліноортопробу встановлено, що 54,9\% учнів мали відхилення від нормальних показників ВР, з формуванням патологічних варіантів: гіперсимпатикотонічного та асимпатикотонічного (таблиця).

\begin{tabular}{|c|c|c|c|c|c|c|}
\hline \multirow{3}{*}{ Вихідний рівень ВТ } & \multicolumn{6}{|c|}{ Тип вегетативної реактивності } \\
\hline & \multicolumn{2}{|c|}{ нормотонічний } & \multicolumn{2}{|c|}{ гіперсимпатикотонічний } & \multicolumn{2}{|c|}{ асимпатикотонічний } \\
\hline & $\%$ & $\mathbf{M} \pm \mathbf{m}$ & $\%$ & $\mathbf{M} \pm \mathbf{m}$ & $\%$ & $\mathbf{M} \pm \mathbf{m}$ \\
\hline Ейтонія $(\mathrm{n}=36)$ & 77,8 & $1,39 \pm 0,09$ & 13,9 & $2,05 \pm 0,34$ & 8,3 & $0,79 \pm 0,1$ \\
\hline Ваготонія $(\mathrm{n}=14)$ & 57,1 & $1,14 \pm 0,17$ & 42,9 & $1,91 \pm 0,22$ & 0 & - \\
\hline Симпатикотонія $(\mathrm{n}=41)$ & 12,2 & $1,48 \pm 0,08$ & 51,2 & $1,90 \pm 0,04$ & 36,6 & $0,60 \pm 0,02$ \\
\hline Усього (n=91) & 45,1 & $1,38 \pm 0,03$ & 35,2 & $1,93 \pm 0,09$ & 19,8 & $0,61 \pm 0,04$ \\
\hline
\end{tabular}

\section{Вегетативна реактивність у обстежених школярів з різним вегетативним тонусом}

При аналізі ВР в залежності від вихідного ВТ виявилося, що нормальна реакція була більш характерною для дітей $з$ ейтонією, при симпатокотонії ейтонічний тип реагування на ортопробу спостерігався в 6,4 рази рідше $\left(\chi^{2}=23,18 ; \mathrm{p}=1,48 \mathrm{E}-06\right)$.

Для дітей $з$ симпатикотонічним вихідним ВТ, напроти більш характерним був гіперсимпатокотонічний тип ВР, який спостерігався в 3,7 рази частіше, ніж при вихідній ейтонії $\left(\chi^{2}=10,3 ; p=0,001\right)$. Звертало увагу на те, що більше ніж у третини щколярів 3 вихідною симпатикотонією простежувалася найбільш несприятлива в прогностичному плані асимпатокотонічна ВР.
Діти 3 ваготонічним типом ВТ майже однаково часто реагували як за нормальним типом ВР, так i гіперсимпатокотонічним.

При аналізі гендерних особливостей встановлено, що у $18,2 \%$ дівчаток 3 ейтонією спостерігався асимпатикотонічний тип ВР, тоді як у хлопчиків цього варіанту реагування не виявлено (рис. 1).

Характеристика типів ВР дітей 3 вихідним симпатикотонічним ВТ демонструє відсутність статистично значимої різниці у виявленні типів ВР хлопчиків та дівчаток. 
Проте патологічний найбільш несприятливий в прогностичному плані асимпатикотонічний тип ВР виявлявся саме при вихідній симпатикотонії (рис. 2).

При цьому IH-2/IH-1 становив у хлопчиків $(0,62 \pm 0,02)$ ум.од., у дівчаток - $(0,58 \pm 0,04)$ ум.од. Виразність гіперсимпатотонічного типу реагування у хлопчиків була меншої $(1,75 \pm 0,08)$ ум.од., ніж у дівчаток $(2,11 \pm 0,10)$ ум.од. $(\mathrm{p}<0,01)$, що може бути обумовленим впливом більш ранніх процесів пубертатної перебудови у дівчаток.
Щодо типів ВР при вихідній ваготонії, то, як видно 3 рис. 3, у всіх дівчаток спостерігався нормальний тип реагування, тоді як у хлопчиків 3 цим типом ВТ частіше реєструвався гіперсимпатотонічний тип ВР, 3 рівнем співвідношення IH-2/IH-1 $(1,93 \pm 0,21)$ ум.од.

Отже, отримані результати звертають увагу на необхідність визначення характеру реагування ВНС на фізичне навантаження, оскільки саме школярі, що мають патологічні типи ВР, в першу чергу потребують реабілітаційних заходів, спрямованих на корекцію функціонального стану ВНС.

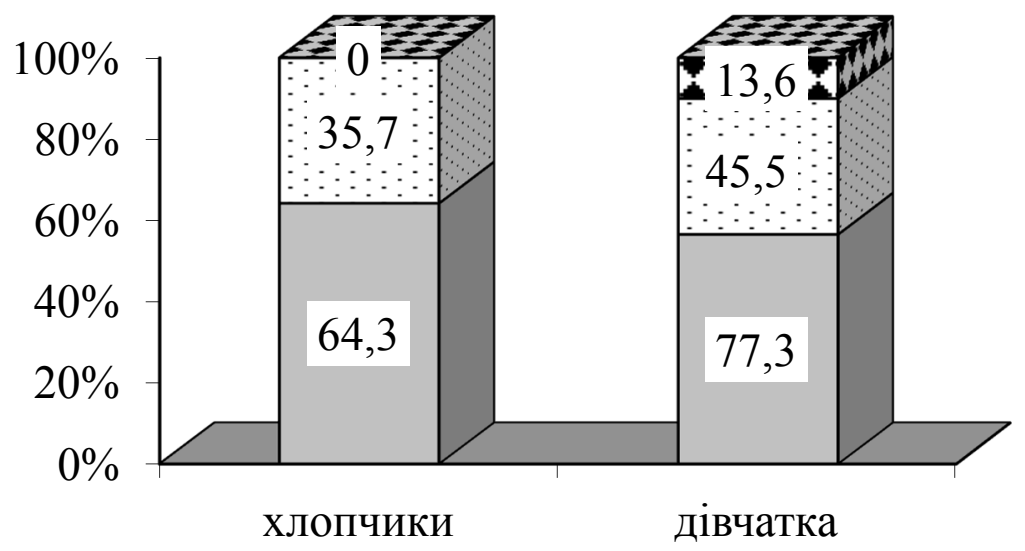

\section{口нормотонічний $\square$ гіперсимпатикотонічний}

Рис. 1. Гендерні особливості розподілу типів ВР у хлопчиків і дівчаток з вихідною симпатикотонією

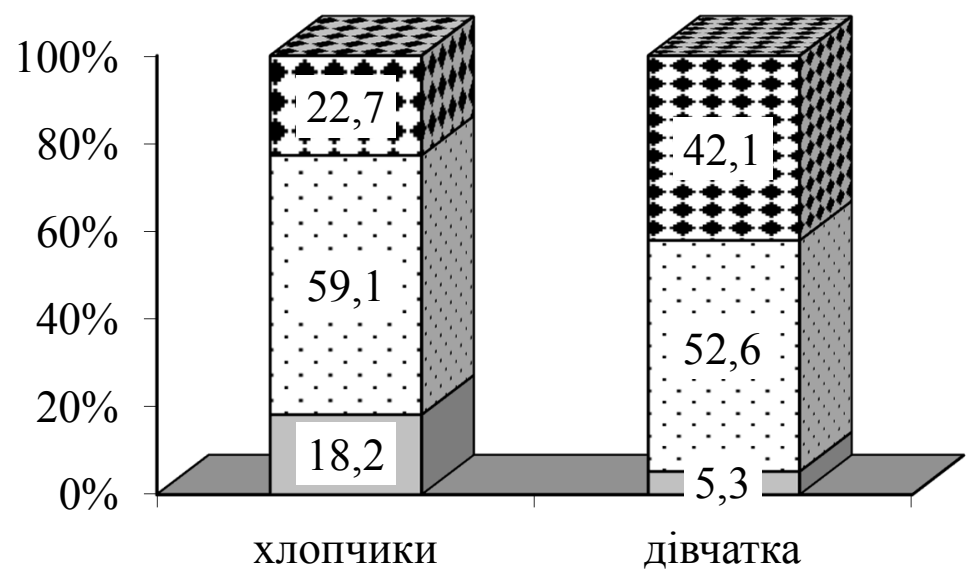

\section{口нормотонічний ๑гіперсимпатикотонічний Ðасимпатикотонічний}

Рис. 2. Гендерні особливості розподілу типів ВР у хлопчиків і дівчаток з вихідною симпатикотонією 


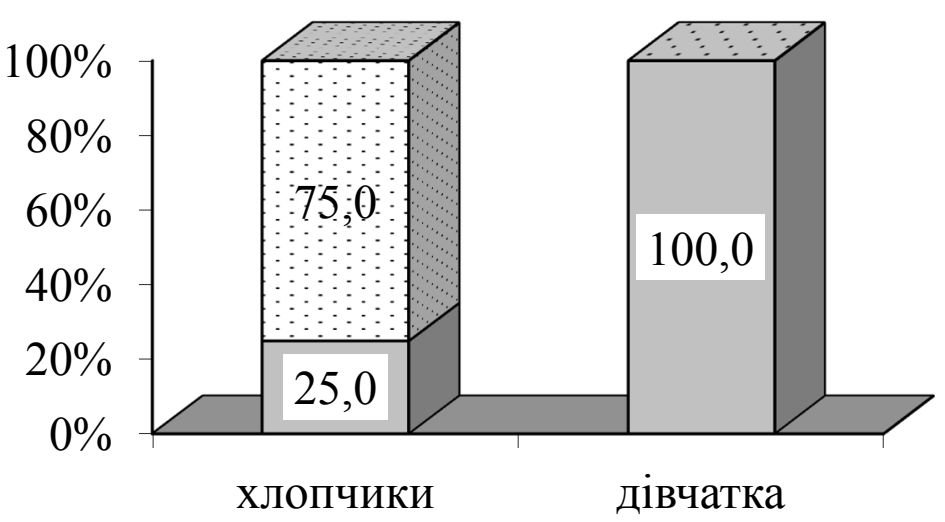

\section{口нормотонічний $\square$ гіперсимпатикотонічний}

Рис. 3. Гендерні особливості розподілу типів ВР у обстежених дітей з вихідною ваготонією

При аналізі адаптаційного потенціалу встановлено переважання дітей 3 функціональним напруженням $(2,57 \pm 0,06)$ бали, що майже 3 однаковою частотою спостерігалося як у хлопчиків $(2,46 \pm 0,08)$ бали, так i дівчаток $(2,67 \pm 0,08)$ бали (рис. 4$)$.
Незадовільні адаптаційні можливості $(3,23 \pm 0,03)$ бали виявлені в поодиноких випадках, але завжди спостерігалися при асимпатикотонічному типі ВР.

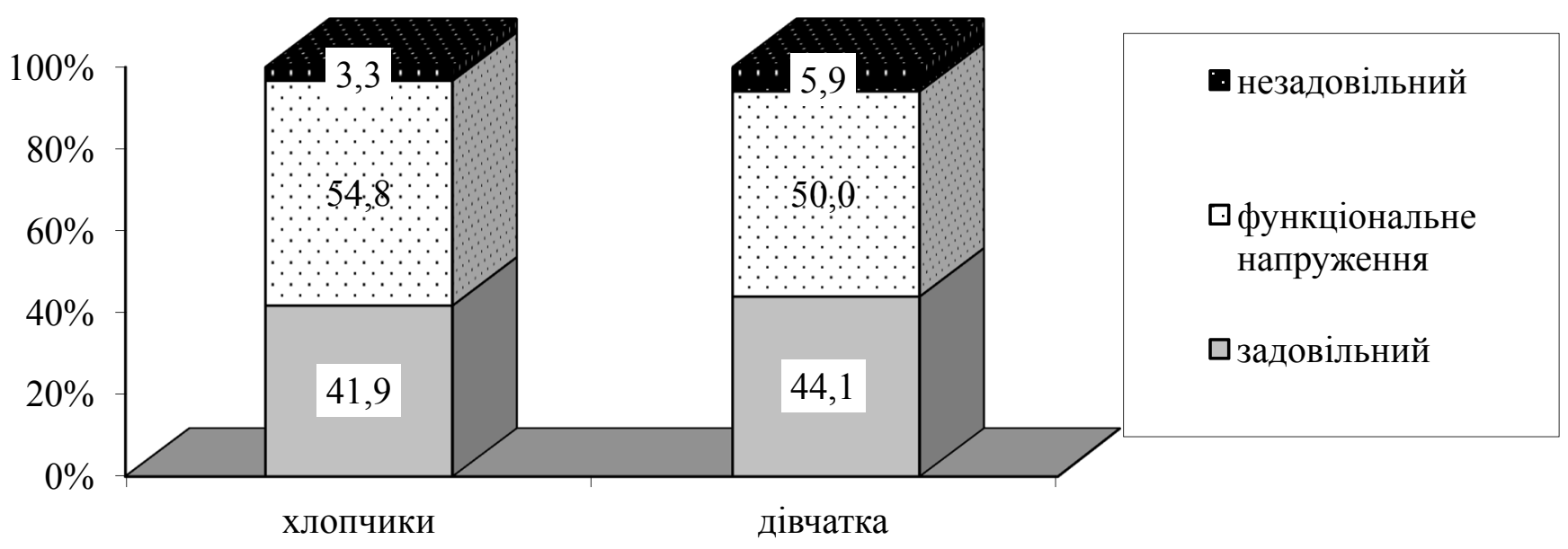

Рис. 4. Частота розподілу обстежених дітей за рівнем адаптаційного потенціалу

Рівень АП зворотно корелював з співвідношенням IH-2/IH-1 $\quad(\mathrm{r}=-0,66 ; \quad \mathrm{p}=0,001) . \quad$ Тобто, як правило, функціональне напруження та незадовільні адаптаційні можливості спостерігалися у дітей 3 гіперсимпатикотонічним та асимпатикотонічним типами ВР.

Таким чином, звертає увагу необхідність визначення характеру реагування ВНС на фізичне навантаження, оскільки саме діти молодшого шкільного віку, що мають патологічні типи ВР, в першу чергу потребують реабілітаційних заходів, спрямованих на корекцію функціонального стану ВНС.
Отже, аналіз фізіологічних параметрів, що характеризують гомеостатичні можливості ВНС, дозволив встановити, що процес вегетативної регуляції у дітей молодшого шкільного віку зі сколіотичною поставою здійснюється в режимі дисбалансу ВНС. Характер його визначається особливостями вегетативної регуляції серцевої діяльності, має гендерні відмінності і відбивається на адаптаційних можливостях організму дітей, що необхідно враховувати при плануванні режимів рухової активності у процесі фізичної реабілітації. 


\section{Лiтература}

1. Скиндер Л.А. Физическая реабилитация детей с нарушениями осанки и сколиозом : учебно-методическое пособие / Л. А. Скиндер, А. Н. Герасевич, Т. Д. Полякова, М. Д. Панкова [и др. ]. - Брест. гос. ун-т имени А.С. Пушкина. - Брест : БрГУ, 2012. -210 с.

2. Turina E.V. Age and sexual features of mental health of children of primary school age / E.V. Turina, T.M. Paranicheva, E.A. Babenkova // Family health in the XII century: Proceedings of the XV International Scientifuc Conference 30 April-7 May 2011.- Torremolinos, Spain. - P. 187-190.

3. Ермолина E. А. Характеристика состояния здоровья и прогнозирование его нарушений у детей с патологией осанки : автореф. дис. на соискание ученой степени канд. мед. наук : спец. 14.00.09 / Ермолина Елена Анатольевна. Ярославль, 2009. - 23 с.

4. Pereira D.S. Relationship of musculoskeletal pain with physical and functional variables and with postural changes in school children from 6 to 12 years of age / D. S. Pereira, S. S. Castro, D. Bertoncello, R. Damião [et al. ] // Braz. J. Phys. Ther. - 2013. -№ 17 (4) -P. 392-400.

5. Криворучко M. Е. Физическое развитие и состояние осанки у детей периода второго детства / М. Е Криворучко// Научные ведомости Белгородского государственного университета. Серия: Медицина. Фармация. 2013. - Т. 24. - № 25-1 (168). - С. 163-165.

6. Кинаш И. Н. Закономерности изменения соматовегетативного статуса больных со сколиотической деформацией после хирургической коррекции : автореф. дис. на соискание ученой степени канд. биол. наук : спец. 14.00.16 / Кинаш Ирина Николаевна. - Иркутск, 2007 - 24 с.

7. Белоконь Н. А. Болезни сердца и сосудов у детей : Руководство для врачей: в 2 томах, Т.1 / Н. А. Белоконь, М. Б. Кубергер - М. : Медицина, 1987. - 448 с.

8. Минвалеева Р. С. Вегетативный индекс Кердо: индекс для оценки вегетативного тонуса, вычисляемый из данных кровообращения / Р. С. Минвалеева // Спортивная медицина. - 2009. - № 1-2. - С. 33-44.

9. Баевский Р. М. Вариабельность сердечного ритма: теоретические аспекты и возможности клинического применения / Р. М. Баевский, Г. Г. Иванов // Ультразвуковая и функциональная диагностика. - 2001. - № 3. - С. $108-127$.

Дата надходження рукопису до редакиї: 30.09.2019 р.

\section{Особенности функціонального состояния вегетативной нервной системы и адаптационных возможностей сердечно-сосудистой детей младшего школьного возраста с нарушением осанки}

Афанасьев С.Н., Майкова Т.В. Приднепровская государственная академия физической культуры и спорта, г. Днепр

С целью оптимизации разработки программы физической терапии для учащихся младшего школьного возраста с нарушениями осанки изучено функциональное состояние вегетативной нервной системы и определен адаптационный потенциал сердечно-сосудистой системы.

В результате исследования вылявлены гендерные особенности вегетативной реактивности детей младшего школьного возраста с нарушениями осанки. Установлено, что в состоянии покоя в 73,3\% мальчиков и $52,2 \%$ девочек преобладал вегетативный дисбаланс с преобладанием симпатикотонии как у мальчиков, при вегетативном индексе Кердо $(30 \pm 1,46)$ усл.ед., так и у девочек $(33,2 \pm$ 2,2) усл.ед.

При определении реакции на клиноортопробу установлено, что 54,9\% учащихся имели отклонения от нормальных показателей вегетативной реактивности, с формированием патологических вариантов: гиперсимпатикотоничного и асимпатокотничного.

При исследовании вегетативной реативности в зависимости от исходного вегетативного тонуса оказалось, что нормальная реакция была более характерна для детей с эйтонией, при симпатокотонии ейтоничний тип реагирования на ортопробу наблюдался в 6,4 раза реже. Для детей с симпатикотоничним исходным вегетативным тонусом, напротив более характерным был гиперсимпатокотоничний тип $\mathrm{BB}$, который наблюдался в 3,7 раза чаще, чем при исходной эйтонии.

Корреляционная связь патологических типов реагирования ВНС с адаптационным потенциалом сердечно-сосудистой системы свидетельствует о напряжении адаптивных механизмов при снижении резервных возможностей вегетативной регуляции, что необходимо учитывать при разработке программ физической терапии для детей младшего школьного возраста с нарушениями осанки.

Ключевые слова: школьники младшего школьного возраста, нарушения осанки, вегетативная реактивность, адаптационный потенциал. 
Functional state features of the autonomic nervous system and the adaptive capabilities of the cardiovascular system in primary school-aged children with postural disorders

Afanasiev S.M., Maykova T.V. Pridneprovska state academy of physical culture and sport, Dnipro

In order to optimize the creation of physical therapy programs for primary school-aged children with postural disorders, the functional state of the autonomic nervous system was studied and the adaptive potential of the cardiovascular system was determined.

The gender features of the autonomic reactivity of primary school-aged children with postural disorders were revealed. It was found that vegetative imbalance with sympathicotonia predominance in both boys with Kerdo vegetative index $(30 \pm 1.46)$ conventional units, and girls (33.2 \pm 2.2 ) conventional unitswas prevalentat rest in $73.3 \%$ of boys and $52.2 \%$ of girls.

It was found out that $54.9 \%$ of students had deviations from normal autonomic reactivity indices with pathological options formation: hypersympathicotonic and asympathicotonic.

When studying the autonomic reactivity depending on the initial autonomic tone, it turned out that the normal reaction was more typical for children with eutonia; with sympathocotonia, the eutonictype of response to an orthostatic test was observed 6.4 times less frequent. For children with a sympathicotonic initial vegetative tone, on the contrary, hypersympathicotonic BB type was more typical, which was observed 3.7 times more often than in the initial eutonia.

The correlation between the pathological types of ANS response and the adaptive potential of the cardiovascular system testifies to the tension of adaptive mechanisms against the decrease in the reserve capacity of vegetative regulation. The results obtained should be taken into account when developing physical therapy programs for primary school-aged children with postural disorders.

Key words: primary school-aged children, postural disorders, autonomic reactivity, adaptive potential.

\section{Відомості про авторів}

Афанасьєв Сергій Миколайович - доктор наук 3 фізичного виховання і спорту, професор, перший проректор 3 науково-педагогічної роботи Придніпровської державної академії фізичної культури i спорту; м. Дніпро, наб. Перемоги, 10.

Майкова Тетяна Володимірівна - доктор медичних наук, професор, професор кафедри фізичної терапії, ерготерапії Придніпровської державної академії фізичної культури і спорту; м. Дніпро, наб. Перемоги, 10. 